\title{
PERAN PERMAINAN TRADISIONAL DALAM MENINGKATKAN MOTORIK KASAR ANAK USIA 5-6 DI RA AL FATTAH PACING PARENGAN TUBAN
}

\author{
Ahmad Farid Utsman ${ }^{1}$ \\ Roudlotun Nikmah ${ }^{2}$ \\ Rohana $^{3}$ \\ IAI Sunan Giri Bojonegoro \\ Faridutsman@gmail.com
}

\begin{abstract}
Abstrak
Perkembangan fisik motorik merupakan salah satu faktor yang sangat penting dalam perkembangan individu secara keselurahan. Keefektifan penerapan permainan tradisional (engklek) dalam merangsang syaraf motorik kasar anak karena dalam permainan tradisional tersebut anak akan menggunakan kemampuan fisiknya dalam bermain. Selain itu, permainan radisional (engklek) bisa dijadikan sebagai warisan budaya, karena agar mereka tahu ternyata permainan tradisional engklek ini mereupakan permainan asli dari nenek moyang mereka, serta permainan engklek ini harus dijaga kelestariannya agar permainan tradisonal engklek ini tidak punah dan terlupakan.

Penelitian ini bertujuan untuk mengetahui bagaimana peran permainan tradisional dalam meningkatkan kemampuan motorik kasar pada anak didik RA Al Fattah Pacing parengan Tuban. Untuk menjawab pertanyaan besar tersebut penulis menggunakan metodologi penelitian kualitatif dengan metode pencarian data menggunakan Observasi, Dokumentasi, dan Interview. Selanjutkan data yang diperoleh akan dianalisis dengan triangulasi data (sumber maupun teknik).

Hasil penelitian menunjukkan bahwa: 1) Permainan tradisional (engklek) sangatlah berperan dalam meingkatkan kemampuan motorik kasar anak didik RA Al Fattah Pacing Parengan Tuban, hal ini dapat dilihat dari indikator banyaknya prestasi yang diraih oleh anak didik RA tersebut pada festival dan kompetisi yang ada hubungannya dengan kemampuan motorik kasar anak, 2) untuk meningkatkan kemampuan motorik kasar anak didik secara berkelanjutan, pendidik terus mengasah kempuan motorik kasar anak didik dengan terus membuat pola kotak-kotak garis engklek dengan variasi yang beragam.
\end{abstract}

Kata Kunci: Permainan Tradisional, Motorik Kasar, Engklek

\section{Abstract}

Physical motor development is one of the most important factors in the overall development of individuals. The effectiveness of the application of traditional games (crank) in stimulating the gross motor nerves of children because in traditional games the child will use his physical abilities in playing. In addition, traditional games (crankshaft) 
can be used as cultural heritage, because in order for them to know it turns out traditional crank games are the original game of their ancestors, and this sustainability game must be maintained so that traditional crank games are not extinct and forgotten. This study aims to determine how the role of traditional games in improving gross motor skills in RA Al Fattah Pacing students in Tuban. To answer the big question the author uses qualitative research methodology with data search methods using Observation, Documentation, and Interview. Then the data obtained will be analyzed by data triangulation (source and technique)

The results showed that: 1) Traditional games (crankshaft) were instrumental in increasing the gross motor skills of RA Al Fattah Pacing Parengan Tuban students, this can be seen from the indicators of the many achievements of RA students at festivals and related competitions with the gross motoric abilities of children, 2) to improve students' gross motoric skills on an ongoing basis, educators continue to hone the gross motoric skills of students by continuing to make crank line pattern patterns with varied variations.

\section{PENDAHULUAN}

Pendidikan merupakan sebuah investasi masa depan bagi kita, dengan pendidikan seseorang dapat bergerak dari satu strata ke strata (atasnya) yang lain. Pendidikan Anak Usia Dini (PAUD) sendiri memiliki definisi yaitu, Usaha pendidikan memfasilitasi perkembangan dan belajar anak sejak lahir sampai dengan usia 6 tahun melalui experience dan rangsangan yang bersifat mengembangkan secara terpadu dan komprehensif sehingga anak dapat tumbuh kembang secara sehat dan optimal sesuai dengan norma yang ada. ${ }^{1}$ Dalam pendidikan anak usia dini kita familiar dengan beberapa jenjang antara lalin: Kelompok Bermain (KB), Pos PAUD, Raudlatul Athfal (RA)/Taman Kanak-Kanak (TK).

Pendidikan anak usia dini pada lembaga Raudlatul Athfal (RA) merupakan lembaga pembinaan yang ditujukan kepada anak sejak usia 4 (empat) tahun sampai dengan usia 6 (enam) tahun. Pendidikan di lembaga RA dilakukan melalui pemberian stimulus pendidikan untuk membantu pertumbuhan dan perkembangan jasmani dan rohani agar anak memiliki kesiapan belajar dalam memasuki pendidikan lebih lanjut. Pendidikan RA dimaksudkan untuk mengembangkan sikap religius dan sikap sosial, pengetahuan, keterampilan, dalam merespon kompetensi dasar di seluruh lingkup pengembangan dan menyesuaikan diri berdasarkan ajaran dan nilai-nilai Islam. Pendidikan RA merupakan fondasi pendidikan, hal ini dikarenakan perkembangan anak di masa setelahnya akan sangat ditentukan oleh berbagai rangsangan yang bermakna dan diberikan pada anak sejak usia dini. Awal kehidupan Anak merupakan masa yang paling tepat dalam memberikan dorongan dan usaha pengembangan agar anak dapat berkembang secara optimal. Salah

\footnotetext{
${ }^{1}$ Khadijah, Konsep Dasar Pendidikan Prasekolah, (Medan: Perdana Mulia Sarana, 2012), hlm. 4.
} 
satu usaha yang dapat dilakukan dalam rangka pengembangan potensi tersebut adalah dengan program pendidikan yang terstruktur. ${ }^{2}$

Perkembangan fisik motorik adalah salah satu dimensi yang sangat penting dalam perkembangan individu secara komprehensif, karena pertumbuhan dan perkembangan fisik terjadi dari bayi sampai dewasa. Aktifitas keseharian anak dipengaruhi oleh perkembangan fisik motorik pada anak. Bila perkembangan fisik motorik anak berkembangan dengan baik, perkembangan yang lain-pun akan berkembang dengan baik juga. Perkembangan fisik merupakan perkembangan semua bagian tubuh dan fungsinya. Antara lain meliputi: perubahan ukuran badan, perubahan bentuk badan, perkembangan otak, perkembangan motorik kasar dan perkembangan motorik halus. ${ }^{3}$

Menurut pandangan Hurlock bahwa perkembangan motorik berarti perkembangan pengendalian gerakan jasmaniah melalui kegiatan pusat syaraf, gerakan urat syaraf, dan otot yang terkoordinasi. Pengendalian tersebut berasal dari perkembangan refleksi dan kegiatan masa yang ada pada waktu lahir. Sepanjang 4 atau 5 tahun pertama kehidupan pasca anak lahir, anak dapat mengendalikan gerakan yang kasar (motorik kasar). Gerakan tersebut melibatkan bagian badan yang digunakan dalam berjalan, berlari, melompat, berenang dan sebagainya. Pasca usia 5 tahun terjadi perkembangan yang lebih besar dalam mengendalikan koordinasi yang lebih baik yang melibatkan kelompok otor yang lebih kecil (motorik halus) yang digunakan untuk menganyam, melempar, menangkap bola, menulis dan menggunakan alat-alat. ${ }^{4}$

Masing-masing individu memiliki potensi yang harus dikembangkan, maka proses pembelajaran yang sesuai adalah menggali potensi anak untuk selalu kreatif dan berkembang. Di lapangan pendidik belum mampu menghadirkan pembelajaran yang bermakna. Banyak pendidik belum siap dengan kondisi yang sedemikian beragam sehingga untuk mendesain pembelajaran yang bermakna masih kesulitan. Pola pembelajaran dengan duduk tenang, mendengarkan informasi dari guru sepertinya sudah menjadi budaya sejak dulu, sehingga untuk melaksanakan perubahan ke arah pembelajaran yang aktif, kreatif, dan menyenangkan masih menjadi sisi sulit sebagian pendidik.

Dimensi lain sebagai media mobilisasi stratifikasi sosial, pendidikan juga memiliki fungsi preventif dan menjaga kearifan budaya lokal. Hal tersebut dapat dijalankan dengan cara hidden kurikulum maupun suatu komponen yang dapat dimasukkan ke dalam kurikulum itu sendiri. Di era perkembangan zaman revolusi industri 4.0, sebagai praktisi pendidikan kita harus pintar mengatur segalanya. Aset budaya (kearifan lokal) yang ada

\footnotetext{
${ }^{2}$ Kurikulum PAUD tahun 2013: Tentang Pendidikan Anak Usia Dini.

${ }^{3}$ Masganti Sitorus, Psikologi Perkembangan Anak Usia Dini, (Medan: Perdana Publishing, 2015), hlm. 4.

${ }^{4}$ Elizabeth B Hurlock, Perkembangan Anak Jilid 1, (Jakarta: Airlangga, 1987), hlm. 150.
} 
pada masyarakat kita jangan sampai hangus hilang begitu saja. Ini merupakan ancaman yang terus mereduksi aset budaya kita. Anak-anak sekarang lebih familiar dengan konten game-game yang ada di smart phone, mereka sudah tidak familiar dengan berbagai banyak permainan tradisional yang diwariskan oleh leluhurnya.

Permainan tradisonal yang diwariskan oleh para sesepuh kita memiliki falsafah yang bermakna. Selain memiliki konten falsafah, permainan tradisonal juga memiliki berbagai manfaat dan minim efek negatif. Banyak permainan tradisional kita dimainkan dengan sistem kebersamaan. Beda dengan game yang ada di smart phone yang lebih menghadirkan cara bermain secara individual. Mereka bagaikan zombie di siang bolong, mereka akan hanyut pada dunia permainannya sendiri tanpa adanya interaksi sosial di kanan kirinya. Efek negatif yang lain juga nampak pada kesehatan fisik seorang anak. Kesehatan mata dan efek radiasi dari game online juga menjadi ancaman nyata bagi kesehatan anak-anak.

Paparan di atas memberikan daya tarik tersendiri bagi penulis untuk melakukan penelitian. Baik berangkat dari perkembangan motorik kasar anak yang selalu membutuhkan stimulus. Dan dimensi (fenomena) sudah ditinggalkannya aset budaya permainan tradisonal oleh generasi penerus, serta bagaimana ancaman efek negatif dari game online maupun permainan yang berbasis smart phone. Di sinilah penulis memiliki pertanyaan besar tentang peran permainan tradisional dalam meningkatkan motorik kasar anak usia 5-6 tahun.

\section{HAKIKAT ANAK USIA DINI}

Banyak para tokoh pendidikan di Indosia memberikan definisi Anak Usia Dini adalah anak yang baru dilahirkan sampai usia 6 tahun, usia ini merupakan usia yang sangat menentukan pembentukan karakter dan kepribadian anak. Usia dini merupakan usia di mana anak mengalami pertumbuhan dan perkembangan yang pesat. Usia dini juga disebut dengan usia emas (golden age). Makanan yang bergizi dan seimbang serta rangsangan yang intensif sangat diperlukan untuk pertumbuhan dan perkembangan tersebut. ${ }^{5}$ Sedangkan menurut NAEYC (National Association for the Education of Young Children) Anak Usia Dini adalah anak yang berusia antara 0 sampai 8 tahun, yang mendapatkan layanan pendidikan di taman pendidikan anak, penitipan anak dalam keluarga (family child care home), pendidikan pra sekolah, tanan kanak-kanak (TK) dan Sekolah dasar (SD).

John Locke sendiri menganalogikan Anak Usia Dini bagaikan Kertas Putih, sehingga lingkunganlah yang mempengaruhi terhadap pembentukan karakter dirinya. Lingkunganlah yang mengisi kertas kosong tersebut yang dinamakan dengan pengalaman.

\footnotetext{
${ }^{5}$ Yuliani Nuraini Sujiono, Buku Ajar: Konsep Dasar Pendidikan Anak Usia Dini, (Jakarta: PT. Indeks, 2009), hlm. 5.
} 
Pengalaman-pengalaman anak akan berpengaruh terhadap pembentukan karakter anak. Teori John Locke ini dikenal dengan Teori Tabula Rasa.

Pada usia dini karakteristik anak sangat berbeda dengan karakteristik yang dimiliki anak pada tahapan di atasnya, berikut ini merupaka karakteristik Anak Usia Dini (AUD), antara lain sebagai berikut:

1. Memiliki rasa ingin tahu yang besar,

2. Merupakan pribadi/individu yang unik,

3. Suka berfantasi atauberimajinasi,

4. Masa potensial untuk belajar,

5. Menunjukkan sikap egosentris,

6. Memiliki rentang daya konsentrasi pendek,

\section{MOTORIK KASAR ANAK USIA DINI}

Perkembangan motorik merupakan perkembangan pengendaliab gerakan tubuh melalui kegiatan yang terkoordinasi antara susunan syaraf, otak, otot, dan spinal cord. Ciri-ciri motorik anak melalui empat tahap:

1. Gerakan-gerakan tidak disadari, tidak sengaja dan tampa arah,

Gerakan anak pada masa ini semata-mata hanyalah dikarenakan adanya dorongan dari dalam. Misalnya: memasukkan tangan ke mulut, mengedipkan mata, dan gerak-gerak lain yang tidak disebabkan oleh rangsangan dari luar.

2. Gerakan anak bersifat khas,

Gerakan yang timbul disebabkan oleh stimulan yang tidak sesuai dengan stimulusnya. Misalnya: jika anak diletakkan suatu benda di tangannya, maka benda itu dipegangnya tidak sesuai dengan kegunaan benda tersebut.

3. Gerakan dilakukan anak dengan masal,

Hampir seluruh tubuhnya ikut bergerak untuk merespon perangsang yang datang. Contoh bila anak diberikan bola, maka harus diterima kedua tangan.

4. Gerakan anak disertai dengan gerakan lain yang sebenarnya tidak diperlukan. ${ }^{6}$

Motorik kasar adalah gerakan tubuh yang menggunakan otot-otot besar atau sebagian besar atau seluruh tubuh. Misalnya: kemampuan duduk, menendang, lari, dan sebagainya. Sedangkan motorik halus adalah gerakan yang menggunakan otot-otot halus atau sebagian anggota tubuh tertentu. Kedua kemampuan tersebut sangat penting agar anak bisa berkembang dengan optimal.

Dalam Peraturan Menteri Pendidikan Nasional Nomor 58 Tahun 2009 landasan tingkat pencapaian perkembangan motorik kasar anak usia 5-6 tahun setidaknya sudah dapat melakukan gerakan tubuh secara terkoordinasi untuk melatih keseimbangan dan

\footnotetext{
${ }^{6}$ Masganti Sitorus, dkk, Pengembangan Kreativitas Anak......, hlm. 88-89.
} 
kelincahan. ${ }^{7}$ Perkembangan daerah sensorik dan motorik pada konteksnya yang memungkinkan koordinasi yang lebih baik antara apa yang diinginkan oleh anak dan apa yang dapat dilakukannya. Tulang dan otot mereka semakin besar memungkinkan mereka untuk berlari, melompat, dan memanjat lebih cepat, lebih jauh dan lebih baik.

Kegiatan-kegiatan yang dapat dilakukan untuk mendukung motorik kasar anak misalnya:

1. Berjalan dengan berbagai gerakan,

2. Mencari jejak,

3. Berjalan seperti binatang,

4. Berjalan naik dan turun tangga,

5. Berbaris, melangkah, berjinjit, berjalan, seperti gerakan kuda liar,

6. Berlari seperti pecutan kuda,

7. Berjalan di tempat,

8. Lompatan kanguru, melompat dengan trampolin kecil,

9. Berjalan dengan papan titian dengan membawa benda (maju-mundur dan ke samping),

10. Mengambil dan meletakkan kepingan dari mangkuk,

11. Melompat seperti katak,

12. Bermain terowongan. ${ }^{8}$

\section{PERMAINAN TRADISIONAL}

Istilah permainan berasal dari kata baku "main" yang mendapatkan imbuhan "per“ dan "an". Dalam kamus Besar Bahasa Indonesia pengertian permainan adalah sesuatu yang dijadikan bermain. Maka dari itu, dapat kita simpulkan bahwa permainan merupakan sesuatu yang dapat dimainkan oleh siapa pun serta mendapat kesenangam. Sedangkan tradisional berarti bahwa sikap, cara berpikir, dan bertindak selalu berpegang pada norma dan adat kebiasaan atau menurut tradisi. Maka dari itu, dapat disimpulkan bahwa tradisional adalah hal-hal yang berkaitan dengan tradisi zaman dahulu yang memiliki nilainilai atau norma-norma kebaikan. Sehingga jika disimpulkan permainan tradisional adalah sesuatu yang dimainkan oleh seorang anak di mana jenis permainan yang dimainkan masih menurut tradisi.

\footnotetext{
7 Permendiknas Nomor 58 Tahun 2009, Tentang Standar Tingkat Pencapaian perkembangan, (Jakarta: Eka Jaya), hlm. 77.

8 Pica, Rae, Permainan-Permainan Pengembangan karakter Anak-Anak, (Jakarta: PT. Indeks, 2012), hlm. 98-99
} 
Menurut Latifa dan Sagala bahwa permainan tradisional merupakan permainan yang dilakukan oleh masyarakat secara turun menurun dan merupakan hasil dari penggalian budaya lokal yang di dalamnya banyak terkandung nilai-nilai pendidikan dan nilai budaya, serta menyenangkan hati yang memainkannya. ${ }^{9}$ Berdasarkan beberapa teori yang telah dikemukan di atas, maka dapat disimpulkan bahwa permainan tradisional merupakan permainan sesuatu permainan yang dapat dimainkan oleh siapa saja, khususnya anak-anak yang dapat menyenangkan hati serta mengandung unsur budaya dan tradisi turun temurun.

Jenis-jenis permainan Tradisional antara lain sebagai berikut:

1. Engklek, congklak, lompat tali, dan tebak-tebak an. Permainan ini selain membantu mengembangkan logika dan fisik anak seperti: berhitung dan dapat juga mengembangkan kemampuan fisik dan bersosialisasi anak.

2. Permaianan petak umpet, gobak sodor, dan benteng-bentengan. Permianan ini bisa dikategorikan ke dalam permainan yang bersifat Olah Raga.

3. Mobil-mobilan, egrang, bola sodoksepak takraw dan calung. Jenis permainan ini akan membantu perkembangan kecerdasan natural anak karena anak diajak untuk berinteraksi dengan lingkungan sekitar.

Dalam bermain mood anak-anak juga dipengaruhi oleh beberapa faktor, antara lain:

1. Kesehatan,

2. Intelegensi,

3. Jenis kelamin,

4. Lingkungan,

5. Status sosial ekonominya.

\section{PERAN PERMAINAN TRADISIONAL DALAM MENINGKATKAN MOTORIK KASAR AUD}

Permasalahan inti penelitian ini adalah peranan permainan tradisional, khususnya permainan engkle di mana implementasi dari pada permainan tersebut di lingkungan RA Al Fatah Pacing Parengan Tuban, diharapkan memberikan dampak positif bagi anak didik, terutama dalam mengembangkan kemampuan motorik kasar anak kelompok A dan B. Berwal dari hal tersebut, maka penulis melakukan observasi keadaan sebenarnya di lapangan. Apakah di lembaga RA tersebut telah diberikan suatu kegiatan yang dapat menstimulasi kemampuan motorik kasar anak dengan pengajaran permainan tradisional, salah satunya adalah permainan engklek.

\footnotetext{
${ }^{9}$ Ulya Latifah dan Chandra Dewi Sagala, Upaya Meningkatkan Interaksi Sosial Melalui Permainan Tradisional jamuran pada Anak Kelompok B TK Kucup Sari Semarang, (Jurnal Penelitian PAUDIA Vol. 3 No. 1, Oktober 2014), hlm. 120.
} 
Setelah dilakukan observasi dan wawancara, serta pembuktian dengan dokumentasi di lapangan dapat dikatakan bahwa kegiatan yang mengarah kepada peningkatan kemampuan motorik kasar anak tergolong sudah cukup memadai dan memang diadakan oleh pihak sekolah. Hasil dari observasi dan wawancara yang dilakukan penulis selama proses penggalian data di lapangan berlangsung bahwa para wali murid menunjukkan antusiasme yang tinggi atas diadakannya pengajaran permainan-permainan tradisional kepada anak didik di RA Al Fattah Pacing Parengan Tuban dalam mengembangkan motorik kasar anak didik. Hal ini dikarenakan aktivitas yang telah berlangsung lama tersebut, telah mempengaruhi tumbuh kembang dan kebiasaan anakanak dalam bermain baik di lingkungan sekolah maupun di rumah bersama teman-teman.

Pada saat anak diberikan stimulasi melalui permainan tradisional engklek terdapat banyak anak yang mampu merubah arah posisi dengan cepat dan tepat. Kecepatan dibagi menjadi dua kecepatan reaksi dan gerak, sedangkan dalam penelitian ini dapat mengembangkan kecepatan reaksi yang merupakan kemampuan seseorang dalam menjawab suatu rangsang dalam waktu sesingkat mungkin. Dengan kebiasaan bermain engklek, anak mampu merespon secara cepat stimulus yang telah diberikan guru. Keseimbangan adalah keterampilan seseorang untuk mempertaghankan tubuh dalam berbagai posisi, dalam tulisan ini kemampuan anak dalam mempertahankan posisi melombat sambil berpindah-pindah tempat dengan kombinasi gerak kaki yang bervariasi sudah dapat dikatakan baik. Hal ini dapat dilihat dari hasil dokumentasi penelitian.

Hasil observasi menunjukkan bahwa motorik kasar anak menunjukkan bahwa motorik kasar anak telah berkembang dengan baik. Hal ini dapat dilihat dari kelihaian anak dalam memainkan permainan engklek tersebut bersama teman-temannya yang sesuai dengan peraturan permainan yang ada. Dengan fakta bahwa permainan tradisonal engklek tersebut dapat memberikan stimulus gerakan-gerakan anak dan melatih koordinasi tubuh, dan secara langsung mengembangkan kemampuan motorik kasar yang dapat bermanfaat untuk kehidupan sehari-hari. kegiatan permainan tradisional engklek merupakan permainan yang dapat menarik anak agar dapat memotivasi anak, melatih kesabaran, ketelitian, dan kedisiplinan dalam bersikap. Motorik kasar yang dilihat atau dikembangkan dalam permainan tersebut, yaitu aspek keseimbangan, kelincahan, dan kecepatan.

Selain itu, peran permainan tradisional engklek dirasa sangat bermanfaat bagi tumbuh kembang anak secara komprehensif, tertutama fisik dan psikis anak-anak. Melalui penerapan permainan tradisional engklek yang diajarkan kepada anak-anak, keterampilan yang melibatkan syaraf motorik kasar anak menjadi terasah. Dengan stimulus permainan engklek, anak didik di RA Al Fattah Pacing Parengan Tuban mampu mengembangkan motorik kasarnya, sehingga hal tersebut membawa mereka mampu menjuarai perlombaan di aspek motorik kasar. Perlombaan tersebut antara lainnya adalah:

1. Ajang kompetisi seni olahraga RA dalam rangka HAB Kementerian Agama tahun 2013. Pada ajang kompetisi olah raga tersebut anak-anak RA Al Fattah 
Pacing Parengan Tuban berhasil menjadi juara II pada kategori Lari Mengisi Air dalam Botol.

2. Porseni IGRA dakam rangka HAB Kementerian Agama 2014. Pada ajang tersebut anak-didik RA Al Fattah Pacing Parengan Tuban berhasil menjadi Juara I pada kategori Lari Estafet.

3. Festival Gebyar PIAUD dan Seni Budaya 2017. Pada festival tersebut anak didik RA Al Fattah Pacing Parengan Tuban berhasil menjadi Juara III pada kategori Lomba Gerak Tari.

Dengan banyaknya perolehan prestasi yang pernah diraih oleh anak-anak RA Al Fattah Pacing Parengan Tuban, semakin jelas dan nyata bahwa permainan tradisonal memberikan dampak posotif yang signifikan bagi perkembangan fisik anak. Hal ini seperti diungkapkan oleh salah satu ahli bahwasanya fungsi permainan engklek salah satunya adalah untuk meningkatkan perkembangan fisik, koordinasi tubuh dan mengembangkan keterampilan motorik kasar. ${ }^{10}$

Berdasarkan uraian di atas, dari data yang diperoleh menunjukkan bahwa kegiatan peningkatan motorik kasar anak akan lebih menyenangkan jika dilakukan melalui permainan. Permainan tradisional seperti engklek adalah permainan yang sangat menyenangkan, memotivasi anak untuk bersikap disiplin terhadap peraturan yang diterapkan pada permainan tersebut, melatigh koordinasi dan keseimbangan badan, dan menstimulasi kemampuan motorik kasar anak. Permainan tradisional engklek juga dapat membantu anak untuk melatih kecepatan, kelincahan di mana mereka dapat secara cepat merespon apa yang harus dilakukan dan membantu kemampuan lain, yaitu keseimbangan dengan adanya modifikasi atau kreasi dalam permainan tradisional engklek.

\section{KESIMPULAN}

Berdasarkan hasil penelitian yang dilakukan dapat disimpulkan antara lain sebagai berikut:

1. Peran permainan tradisional (engklek) dalam meningkatkan motorik kasar anak usia 5-6 tahun di RA Al Fattah Pacing Parengan Tuban berjalan dengan baik. Serta pengaruh atau perannya sangat signifikan dengan indikator diraihnya gelar berbagai iven kompetisi dan festival yang membutuhkan kemampuan motorik kasar anak.

2. Pendidik memegang peranan penting untuk terus mengasah, mengasih, dan mengasuh kemampuan motorik kasar anak dengan berbagai varian bentuk kotakkotak yang digunakan permainan tradisional engklek, pendidik juga memberikan motivasi, trik, dan reward kepada anak didik.

${ }^{10}$ Khadijah, Konsep Dasar Pendidikan Pra....., hlm. 152. 


\section{DAFTAR PUSTAKA}

Andriani, Tuti. 2012. Permainan Tradisional Dalam Membentuk Karakter Anak Usia Dini, (Jurnal Sosial Budaya Vol. 9 No. 1 Januari-Juli 2012).

Arifin, Zaenal. 2008. Metodologi Penelitian Pendidikan Filosofi, Teori \& Aplikasinya. Surabaya: Lentera Cendekia.

Dramamulya, Sukirman. 2005. Permainan Tradisional Jawa. Yogyakarta: Kepal Press.

Faqih, Abdul Latif. 2008. Rahasia Segitiga Allah, Manusia, dan Setan. Jakarta Selatan: Hikmah PT. Mizan Publika.

Hurlock, elizabeth B. 1987. Perkembangan Anak Jilid 1. Jakarta: Airlangga

Khadijah. 2012. Konsep Dasar Pendidikan Pra-Sekolah. Bandung: Cipta Pustaka Media Perintis.

Nur, Haerani. 2013. Membangun Karakter Anak Melalui Permainan Anak Tradisional. Makasar: Jurnal FP Universitas Negeri Makasar.

Permendiknas Nomor 58 tahun 2009. Tentang Standar Pencapaian Perkembangan. Jakarta: Eka Jaya.

Pica, Rae. 2012. Permainan-Permainan Pengembangan karakter Anak-Anak. Jakarta: PT. Indeks.

Sitorus, Masganti. 2016. Pengembangan kreativitas Anak Usia Dini Teori dan Praktik. Medan: Perdana Publishing.

Sujiono, Bambang. 2010. Metode Pengembangan Fisik, Jakarta: Universitas Terbuka.

Sujiono, Yuliani Nuraini. 2007. Buku Ajar: Konsep Dasar PAUD. Jakarta: Universitas Negeri Jakarta.

Suyanto, Slamet. 2005. Dasar-Dasar Pendidikan Anak Usia Dini. Yogyakarta: Hikayat Publishing.

Yamin, dkk. 2010. Panduan Pendidikan Anak Usia Dini PAUD. Jakarta: Gaung Persada. 